\title{
SER LIBRE, ACTUAR CON LIBERTAD Y LIBERARSE. PETER MCLAREN Y LA PEDAGOGÍA DE LA LIBERACIÓN*
}

Resumen: McLaren, en esta entrevista, reflexiona sobre diferentes enfoques en el ámbito de la pedagogía crítica y se detiene en interpretaciones que se han derivado de la obra de Freire, incidiendo en la necesidad de reflexionar sobre la propia práctica para encontrar formas que posibilitan que personas oprimidas se conviertan en protagonistas de la historia. Así mismo, este autor explica como parte de su trabajo se centra en dar fuerza a los movimientos anti-capitalistas en Norte América y formular una alternativa al capitalismo global, reflexionando sobre el papel que puede jugar en ello la pedagogía crítica. Destaca el papel clave del profesorado en el desarrollo de pedagogías anti-capitalistas en el seno de las actuales sociedades cambiantes, afectadas por acontecimientos internacionales como la elección de Obama o la crisis económica, donde las escuelas pueden convertirse en espacios para la producción de conocimiento crítico y para la acción sociopolítica.

Palabras clave: movimientos anti-capitalistas, conocimiento crítico, acción sociopolítica.

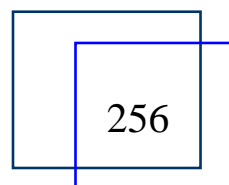

Peter McLaren

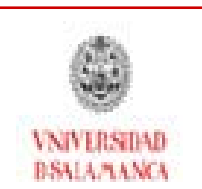




\begin{tabular}{c|c} 
Revista Electrónica Teoría de la Educación. \\
Educación y Cultura en la Sociedad de la Información.
\end{tabular}

\section{BEING, BECOMING AND BREAKING-FREE: PETER MCLAREN AND THE PEDAGOGY OF LIBERATION}

Abstract: In this interview, McLaren reflects on different approaches to the field of critical pedagogy and lingers over interpretations derived from the work of Freire, underlining the need to reflect on practice itself in order to find ways which allow oppressed people to become protagonists in history. Likewise, this author states that part of his work is focused on supporting anti-capitalist movements in North America and formulating an alternative to global capitalism, reflecting on the role which critical pedagogy could play in this. He underlines the essential role of teachers in the development of anti-capitalist pedagogies within the heart of today's changing societies, affected by international events such as the election of Obama or the financial crisis, in which schools can become spaces for the production of critical knowledge and for socio-political action.

Keywords: anti-capitalist movements, critical knowledge, socio-political action.

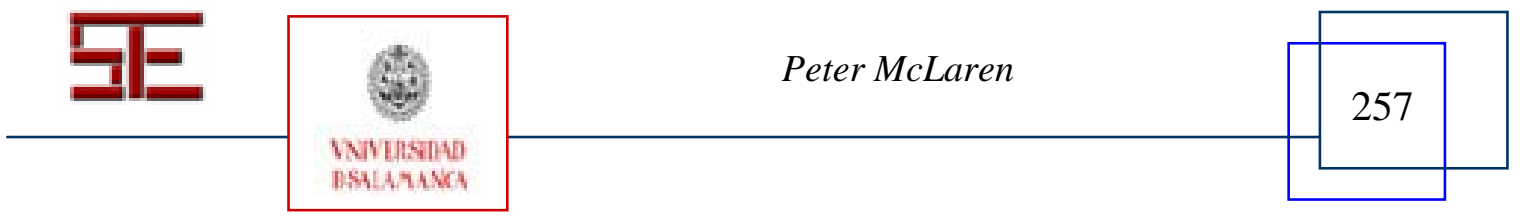




\section{BEING, BECOMING AND BREAKING-FREE: PETER MCLAREN AND THE PEDAGOGY OF LIBERATION}

Peter McLaren.

mclaren@gseis.ucla.edu

University of California.

1. You have been in the forefront of revolutionary critical pedagogy along with other social scientists. Where does the break happen in the works of revolutionary critical pedagogues from that of earlier educationists - the neo-Marxists like Michael Apple or critical pedagogues such as Henry Giroux?

I don't see it so much as a break or rupture as coming to a fork in the road, a fortuitous crossroads of sorts - and deciding to take a different path, recognizing that the journey I had taken with fellow critical educators had been a long and arduous one, freighted with travails and tribulations, a voyage where a lot of learning had taken place and many important struggles had been initiated. Apple's work was important to me as a graduate student because it was a clear exposition of a neo-marxist analysis of the North American curriculum and policy initiatives and Giroux's work -where I find more similarities to Zygmant Bauman, Castoriadis, and the Frankfurt school than to the revolutionary Marxist tradition out of which my more recent work has emerged - remains important to me to this day; I consider Henry one of the most important public intellectuals of our generation and one of the most important critics of contemporary social formations, including the behemoth we refer to as neoliberalism. His creative and brilliant work on so many topics has inspired an entire generation of intellectuals. What's different among us? Well, I think many things, and I would point to the most significant as my preoccupation with the writings of Marx, my hoisting of class as a central concept in teacher education, and the creation of socialism for the twenty-first century and linking education to the worldwide struggle for socialism, and working towards the instauration of Marxist educational theory in North America, along with a few fellow travelers. That path was opened up to me, in part, by the work of British educationalists Dave Hill, Mike Cole, Glenn Rikowski and Paula Allman. Back in the mid 1980s,

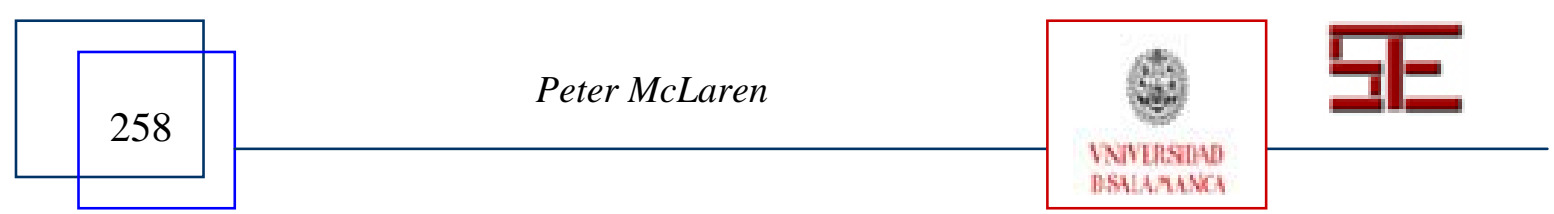




\begin{tabular}{c|c} 
Revista Electrónica Teoría de la Educación. \\
Educación y Cultura en la Sociedad de la Información.
\end{tabular}

Mike Cole challenged me to subject my own work to a Marxist critique and I am glad that I obliged. Now I think your question leads to a more important question — what differentiates my work in general from the progressive tradition in North America? In the early 1990s I was working from a perspective I called critical postmodernism - the term critical postmodernism or resistance postmodernism was used, after Teresa Ebert, to distinguish it from 'ludic postmodernism' or the postmodernism of the spectacle, of the theatrical apparatuses of the state, the politics of representation and the propaganda of desire, a pedagogy of "arousal effect", a kind of micro-resistance linked to a secret museum of academic codes and codices that existed within culture where culture's mystified nature could be explored and a politics of negation unleashed, the aim of which was to produce a well-tempered radical where the alienation of everyday life under capitalism was seen as not so bad because it was suffered by good people. I was concerned that, among the cultural avant-garde, questions of class became ideationally sequestered from internal scrutiny - there existed a proclivity to self-censorship related to questions of class because the working-class in their role as organic intellectuals were relegated to the role of cultural workers, and needed tutelage in the spaces of the vanguard regarding questions of cultural production whereas questions of class were deemed to be self-evident and to some extent naturalized. Now I don't want to leave you, Ravi, with the impression that I don't think culture is very important, since culture is linked to ways of "living out" historically specific Given that the politics of liberation is headquartered in critical consciousness and ignited by revolutionary praxis where historical agents transform themselves through their struggles, I tried to create pedagogical spaces that could make the strange familiar and the familiar strange, more specifically in the sense of accounting for the "rich totality of many determinations" that Marx talks about. In other words, I tried to do a number of things: to understand how a distracted and indifferent subjectivity (that led to critics bemoaning the superficiality of modern life), one that remains blasé to shifts and changes within a moving modernity, can be invited into new perceptions of the social self by building a critical lexicon gleaned from the critical literature; to make the subterranean or oblivious workings of capital more conspicuous to teachers and educators, to conceive of the concept of praxis as ontologically important, and examine history not as something already written or hardwired into predicated or predictable outcomes but open to change once certain ideological and material conditions are superceded and fetishized everyday life grasped dialectically (i. e, those conditions that shape and educate our desires surreptitiously or in tacit ways). I wanted to add some dialectical flesh to the progressive bones of critical pedagogy (which had becoming increasingly domesticated, as Paulo Freire was turned into a type of benevolent, almost Santa Claus figure), and tried to give this flesh an almost raucous, ribald and garrulous physicality through an eclectic writing style without becoming trapped in a phenomenology of sensation or seduction. I tried to understand in theoretical terms, what gives our desires direction? And, of course: What is the direction of our desiring? I became interested in the notion that human beings form reality in the process of becoming human, that praxis determines human beings in their totality, in other words, that praxis distinguishes the human from the non-human, which is something Karel Kosik talked about in his work on the dialectics of the concrete. Fol-

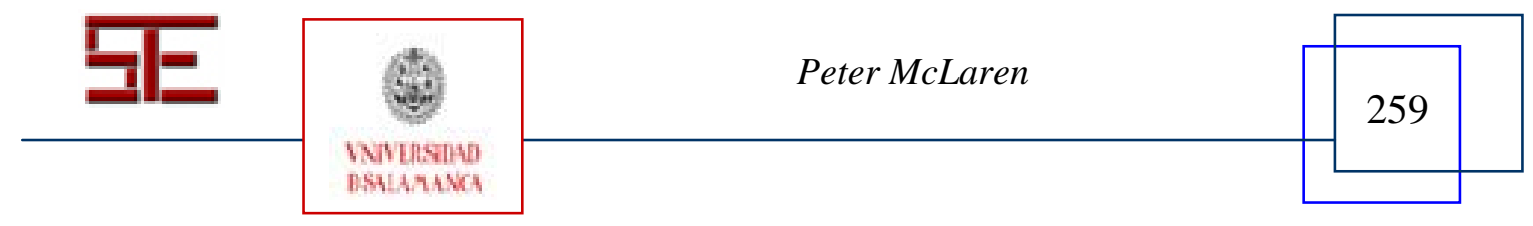


lowing Kosik, I became interested in the movements of the world's totality and how this totality is uncovered by human beings, and how, in our uncovering this totality we develop a particular openness towards being. How can we discover ourselves as historical beings? The results of our actions in and on and through the world do not coincide with our intentions. Why is this? What accounts for the disharmony between the necessity and the freedom of our actions as human beings creating and being created by historical forces? These are questions that motivated my thinking, and still do. Do we make history or are we agents of history? I do not believe we are summoned by some higher power to create historical outcomes but that, following Marx, we make history. Kosik saw this as the interconnection of objectified and objectivised praxis of humankind. This praxis in the form of production forces, forms of thought, language, etc., exists as historical continuity only because of the activity of human beings. But this objectified and objectivised praxis has a form, and it is this form which is fixed in human history and seems over time to be more real than human reality itself and becomes the basis for historical mystification, of what Kosik refers to as the basis of the possibility of inverting a subject into an object. So, in effect, this forms the possibility for ideological mystification, for the ideological state apparatuses, all the way to the current kind of totalitarianism we had under the Bush administration ruled by the "big lie" - a lie that enters people's heads as if it were a metaphysical being, a mystical substance in which human beings seek a guarantee against chaos, against chance, against the everyday contingency of life. So that every individual enters conditions not of their own making, there is a dialectic we must uncover between individuals and conditions that are given for every generation, epoch and class and as Kosik noted, we can transcend these conditions but not primarily in our consciousness and intentions but through our praxis. We get to know the world by actively interfering in it. We discover our revolutionary ethics in the process of our objectification and our resistance to it. I tried to convey to my students that economics is not some nomothetic discipline but an ethic - a moral philosophythat is perverse because of the way it deals with practical, human relationships through its frenzy to maximize profits. I became interested in the work of Raya Dunayevskaya and her notion of absolute negativity. Absolute negativity, in Raya's sense of the term, does not refer simply to an endless series of negations but a negation that can free itself from the object of its critique. Raya discovered this in Hegel. Hegel worked with a type of self-referential negation which was modified by Marx. By negating itself, negation establishes a relation with itself and is freed from dependence on the external object so this type of negativity, since it exists without relation to another outside itself is absolute- it is absolved from dependence on the other. This type of negation has negated its dependence on an external object. Marx critically appropriated this concept to explain the path to communist society. As Peter Hudis has explained, Marx via Hegel understood that to negate something still leaves us dependent on the object of critique. The alienated object is simply affirmed on a different level. So when you look at revolutions of the past, you see that they were still trapped by the objects that they tried to negate. They didn't fully negate their negations, so-to-speak. Along these lines, Peter Hudis notes that communism is the negation of capitalism but as such it was still dependent on the object of its critique insofar as it replaced private property with collective property.

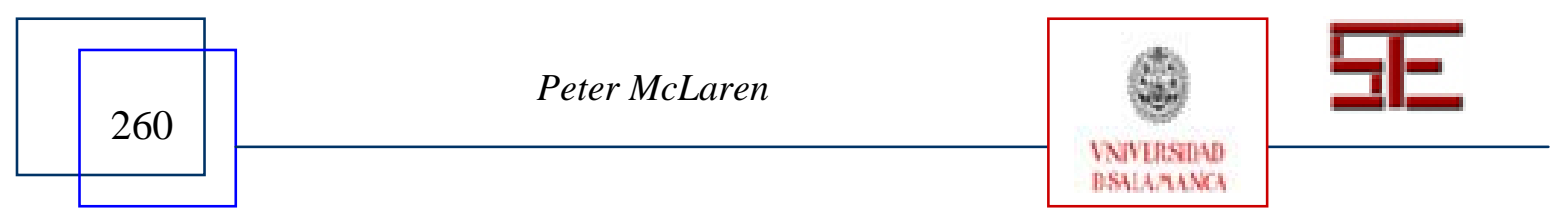




\begin{tabular}{c|c}
\hline 1 & $\begin{array}{c}\text { Revista Electrónica Teoría de la Educación. } \\
\text { Educación y Cultura en la Sociedad de la Información. }\end{array}$ \\
\hline & TESI, 10(3), 2009, 256-281
\end{tabular}

Communism thus was not free from the alienated notion that ownership is the most important part of being human. Ownership was still affirmed, but on a different level. Of course, it was good to negate private property but this did not go far enough to pave the way to a truly new, a truly positive society. In order to achieve this you need a human praxis that can achieve the transcendence of alienation. And this necessitates a subjective praxis connected with a philosophy of liberation that is able to illuminate the content of a post-capitalist society and convincing the popular majorities that it is possible to resolve the contradictions between alienation and freedom. Now it is clear that attempts to concretize absolute negativity as a new beginning rather than repeating the mistakes of an earlier era have been halted by the forces of colonization and imperialism. The work of Ramón Grosfoguel, Nelson Maldonaldo-Torres, Enrique Dussel, Walter Mignolo and Aníbal Quijano and others are writing cogently and presciently about the coloniality of being in this regard, where the epistemological genocide linked to the Eurocentric forces of colonization, and economic exploitation linked to capitalism are demonstrated to be co-constitutive of plundering the oppressed (invented non-beings) of their alterity, their liberty, and their humanity — where, as Enrique Dussel notes, indigenous peoples have become but free labor for a colonial tributary system linked historically to European capital. I am interested in the historical process of the European ego's missionary sense (I discover, I conquer and I evangelize) and ontological sense (I think) and how this links up to the concept of the transnational capitalist class and the transnational state apparatus as developed by William Robinson.

2. Freire, with whom you have worked and whose ideas have been critically used by you in your works, has been used by different shades of intellectuals as well as even agencies that sustain the rule of capital. What is it that allows the use of Freire's works/ideas by them and what difference does it make when you use his ideas in your works?

Well, I make no claim to a 'purer' interpretation of Freire's work. I think of the influence that Karel Kosik's Dialectics of the Concrete had on Freire, and I think we can understand Freire best when we see his work in terms of how he fashioned the notion of praxis. In this respect, I would argue that Freire's work has been flensed by liberals. The politics of his praxis has been pasteurized. The supreme postulate - the unity of theory and practice - is upheld by liberals and criticalists alike - but the original philosophical questioning (at least within materialist philosophy) that formed the conditions of possibility for revolutionary praxis has disappeared. Thus, as Kosik notes, the unity of theory and praxis has come to be realized and grasped in different epochs in very different ways. Liberals often deal with the pseudo-concrete when utilizing praxis they view it in terms of addressing the practical applications of pedagogical theory, or something like that, in which the focus is on the subjective consciousness of the individual. Praxis in the way I understand it, via Freire, and others, is the ontological process of becoming human. Reality manifests itself in this becoming, in this ontoformative process of becoming, in which the practice of being human forms and inter-

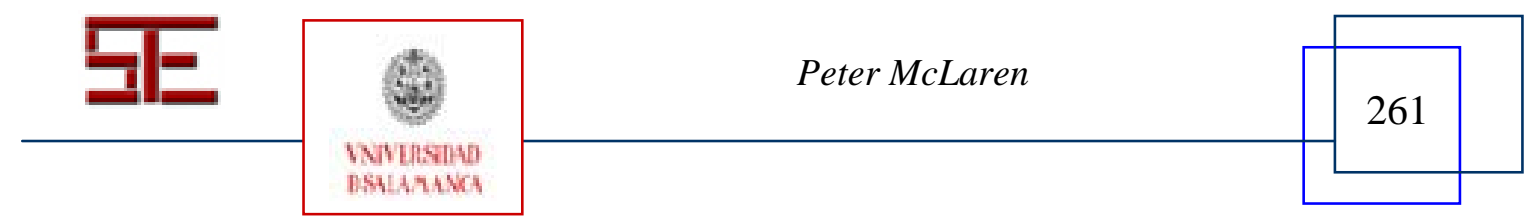


prets reality. So praxis, as Kosik points out, is a specific mode of being that determines humans in their totality.

A specific mode of being, praxis becomes a way of transcending our finitude and helps us to constitute our relationship to the totality of human existence. Many approaches to knowledge limit the notion of praxis, fetishize it, and turn it into some kind of technique of learning. Here, formal logic replaces dialectical logic. This goes against a materialist philosophy of praxis in which praxis is viewed as an onto-formative process, as the historical mediation of spirit and matter, of theory and action, epistemology and ontology. Here we need to talk about revolutionary praxis, denouncing oppression and dialectically inaugurating new forms of social, educational and political relationships. Clearly, reflecting on our practice means finding ways of organizing and activating our pedagogical relationships so that the oppressed become protagonists in historical formation. Freirean praxis is oriented towards socialist relationships and practices, and this has been jettisoned by liberals.

3. The works of revolutionary critical pedagogues have been often critiqued as nonviable, as ideals which cannot be achieved. Their works are also critiqued on grounds that they do not talk much about curriculum, teacher training, classroom transactions or students psychology. Rather they are seen as arguing against imperialism and capitalism or resistance against capitalism. How would you respond to such critiques?

I think there is some truth to this criticism. But there are several ways to look at this dilemma. First and foremost, if there are no other critical educators addressing neoliberal capitalism and imperialism, specifically from a Marxist perspective, or dealing systematically with what Aníbal Quijano and Ramón Grosfoguel call the "coloniality of power" then it is obvious revolutionary critical educators need to be up to this task. It seems obvious to me that the work of postmodern left has remained regnant in the education literature --Hardt and Negri's work on the immateriality of labor, and the like. As well as concepts such as class taught from traditional Weberian or neo-Weberian perspective. And there are too few Marxist analyses available for students to engage within the educational field, although perhaps it is different in India, and I know that it is different in England with the work of Dave Hill, Mike Cole, Glenn Rikowski, Paula Allman, and others gaining worldwide visibility. So in terms of my own work, I have been trying to address issues that you and colleagues in England and elsewhere have been addressing for a much longer time. My task, along with other North American critical educators, has been to try to give the anti-capitalist movement relevance for North American educators. One theme that has dominated my work has been a Marxist critique of global captialism. The sociologist William I. Robinson argues that we have a global capitalist system that has entered a new phase during the last two decades --what we have come to call neo-liberal capitalism. Obviously we need to mount a politics of resistance. Social and political forces are still needed to challenge state power at the national level. It is wrong to think that there is no more need to talk about state power or

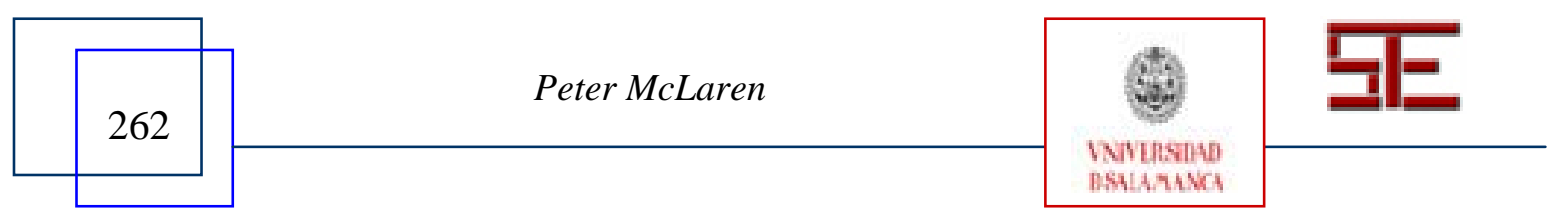




\begin{tabular}{c|c}
\hline 1 & $\begin{array}{c}\text { Revista Electrónica Teoría de la Educación. } \\
\text { Educación y Cultura en la Sociedad de la Información. }\end{array}$ \\
\hline & TESI, 10(3), 2009, 256-281
\end{tabular}

the need for political organizations that can cooperate in civil society as well as in political society. We have two extremes at the current historical juncture: the old model of the vanguard party overthrowing the state (the vertical model) and the civil societarian position about changing the world without taking state power. And Robinson is correct in positing a crucial remaining question: What types of political vehicles will "interface" between popular forces and state structures? What's the relationship between the social movements of the left, the state, and political organizations? Previously the relationship was vertical (cultivating a top down hierarchy), now it's horizontal (cultivating democratic social relations from the ground up). So what will eventually replace the neo-liberal model? Market capitalist models? Reformist models that will sustain the rule of capital? What are the forms of organization we need to resist the rule of capital? At the level of the state as well as the public sphere. What political vehicles can the popular majorities create that can interface between popular forces and state structures? How can popular forces utilize state power in order to transform the state and bring about a socialist alternative to the capitalist law of value? According to Robinson, previously there was a vertical model. In the last 15 or 20 years, the emphasis has been on horizontal relations, networking among different social groups, and bringing about democratic relations from the ground up via participatory democratic forms of organization. Here, indigenous organizations have taken the lead. We need countervailing forces from below--popular forces and movements of popular majorities from below that can put pressure on the state (where global forces pressure even revolutionary governments to moderate structural change), even when the state is working towards socialist ideals such as the case of Venezuela. What are the pedagogical implications in all of this? How can we look at critical pedagogy as a social movement, as a broad coalition of groups? How do we define pedagogy in this context? How is critical pedagogy a force for change that exists as much outside of schools as within them? These are questions that need exploring. And there are too few of us in the field of education engaging these questions.

Let's take another important theme. In addition to challenging the neo-liberal globalization of capital, revolutionary critical educators need to address the concept of colonialism. Aníbal Quijano, for instance, notes that with the help of capitalism, the idea of race helped to yolk the world's population into a hierarchical order of superior and inferior people and it became a central construct in creating and reproducing the international division of labor, including the global system of patriarchy. He writes how, historically, slavery, serfdom, wage labor, and reciprocity all functioned to produce commodities for the world market --and this "colonial power matrix" ("patrón de poder colonial”) came to affect all dimensions of social existence such as sexuality, authority, subjectivity and labor. Berkeley professor Ramon Grosfoguel conceptualizes this as a historicalstructural heterogeneous totality that by the late 19th century came to cover the whole planet. Grosfoguel has described the coloniality of power as an entanglement of multiple and heterogeneous global hierarchies ("heterarchies") of sexual, political, epistemic, economic, spiritual, linguistic and racial forms of domination and exploitation where the racial/ethnic hierarchy of the European/non-European divide transversally reconfigures all of the other global power structures. As race and racism became the organizing

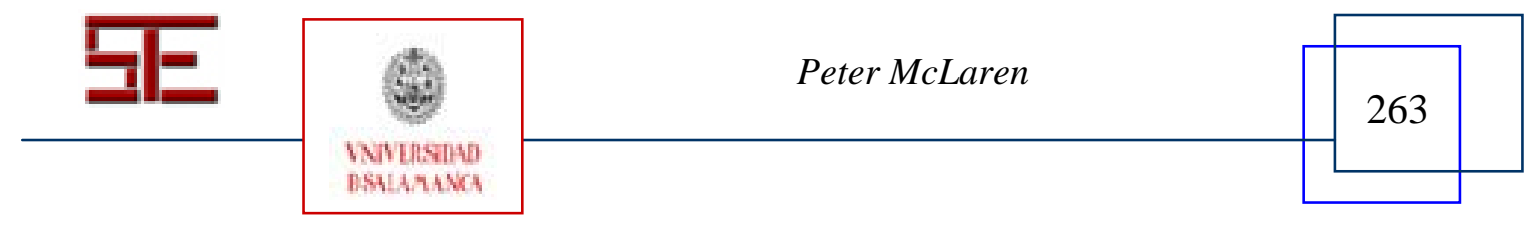


principle that structured all of the multiple hierarchies of the world-system, different forms of labor that were articulated to capitalist accumulation at a world-scale were assigned according to this racial hierarchy. Cheap, coercive labor was carried out by non-European people in the periphery and "free wage labor" was exercised in the core. Such has been the case up to the present day. Grosfoguel makes an import case that, contrary to the Eurocentric perspective, race, gender, sexuality, spirituality, and epistemology are not additive elements to the economic and political structures of the capitalist world-system, but a constitutive part of the broad entangled "package" called the European modern/colonial capitalist/patriarchal world-system. Now as revolutionary critical educators, we need to examine class struggle in the context of the production of the coloniality of power. This is an important project. So yes, this is a lot of theoretical work, and the basic arguments need to be laid out before we can build a curriculum that can address these issues and more work needs to be done before we can mine their implications for teacher education, curriculum, and a psychology of liberation. When we look at psychology, we can look to the pioneering work of Frantz Fanon and, of course, Ignacio Martín-Baro, the Jesuit priest who was murdered by the state in El Salvador. Of course, some educators are addressing the issue of decolonizing pedagogy at the level of the classroom, of decolonizing the curriculum, and this is important work. It is not that work addressing these themes has not been done before for many years. It's just that when new questions and configurations arise at the level of global politics, we need to examine their implications from both geopolitical and micropolitical perspectives, using new conceptual schema and utilizing empirical work being done on the ground. And putting it all together.

But, Ravi, a single revolutionary critical educator would find it difficult to do everything you mention in your question all at once --to put implications for curriculum planning, for learning theory, for psychology, for teacher education, for pedagogical approaches in the classroom all in one book, or one study, for instance. I like to see revolutionary critical education as a collective enterprise. Some critical educators are writing about classroom issues, others are looking at the curriculum. I am writing more on a "macro" level, trying to develop a coherent philosophy of praxis-and of course I benefit from the work being done by critical educators worldwide. If I were a pre-service student in a teacher education program, obviously reading a book by McLaren would not be enough to answer so many important pressing questions that classroom practitioners need to address. The key would be to read educators who can give you some philosophical foundations, including the concept of revolutionary praxis, some historical foundations, ethical and epistemological foundations, and some multicultural foundations that include issues around gender and patriarchy and sexuality and disability, and foundations for developing critical classroom practices, including eco-pedagogy and teaching for a sustainable biosystemic future. We are a collective effort. People sometimes want me, or some other revolutionary critical educator, to do everything in a single text. The key is not to look for a single source but to appropriate critically from a wide expanse of revolutionary critical discourses --inside and outside of the educational literature. Here in the US we have a field called educational foundations. But you don't see programs called educational foundations as much today as when I began teaching in schools of

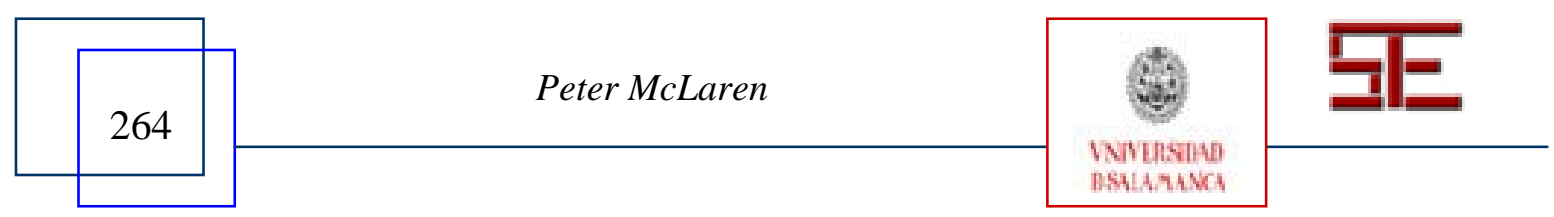




\begin{tabular}{c|c}
\hline 1 & $\begin{array}{c}\text { Revista Electrónica Teoría de la Educación. } \\
\text { Educación y Cultura en la Sociedad de la Información. }\end{array}$ \\
\hline & TESI, 10(3), 2009, 256-281
\end{tabular}

education a number of decades ago. I think we need to revive educational foundations, and try to revision them as critical educational foundations programs.

The state is not a neutral site, and what we need to challenge is how capital has shaped it and how it is shaping capital. Civil society is part of the the state and is not an autonomous region that miraculously floats above the messy world of class antagonisms. Many progressive educators fail to realize this. So what happens? In their refusal to move beyond reclamation of the public sphere and an embracing of an anaemic and abstract conception of democracy and freedom, they unwittingly reflect the leftist face of the capitalist class in which appearances are created and preserved while reality is eroded. For me, the struggle is about building a socialism of the concrete, not an abstract utopia, a radical democracy of the abstract. And we all have been remiss is failing to spell out what this means, what this could like like. That is the challenge for some of us, and until we develop a coherent direction of where to go AFTER capital, then we will be trapped in a leftist neoliberalism, and that is a very perilous place to be for humanity.

\section{Two events have dominated news recently - global recession and election of Obama as President of USA. How do you analyse the recession as a pedagogue? How do you see it as a teacher-worker affecting the educational scenario?}

Teachers need to develop anti-capitalist pedagogies. They need to involve their students in a discussion of the current global economic crisis - and not be afraid to use the word "capitalism". We need to stress the "class" dimension of the crisis in Marxian terms. We need to enter into discussions about how capitalism works and how the question of politics pervades questions of the economy and the distribution of wealth and class power. And how all these questions have a moral dimension (can morality exist within capitalism?) as well as a political basis. There is a tremendous fear about socialism in the United States these days, but we must remember that the ruling class only fears socialism for the poor because the entire system is protected via a socialism for the rich, a system that is comfortably in place - although it needs to be unmasked as socialism for the rich. The great US polymath, Gore Vidal, pointed out that the US government prefers that "public money go not to the people but to big business. The result is a unique society in which we have free enterprise for the poor and socialism for the rich" and we can clearly discern the truth in that statement when we look at the recent nationalisation of Fannie and Freddie where you can see clearly that the USA is a country where there exists socialism for the rich and privatization for the poor, all basking in what Nouriel Roubini calls "the glory of unfettered Wild West laissez-faire jungle capitalism" and what Marxist theorist David Harvey argues has led to "a financial Katrina"-that has allowed the biggest debt bubble in history to fester without any control, causing the biggest financial crisis since the Great Depression. Indeed, socialism is only condemned when it profits the poor and the powerless and threatens the rich. But capitalists are quick to embrace a socialism for the rich — which really is what neoliberal capitalism is all about. But of course, it's called free market capitalism and is seen as synonymous with the struggle for democracy. But free market ideology cannot fix a crisis created by

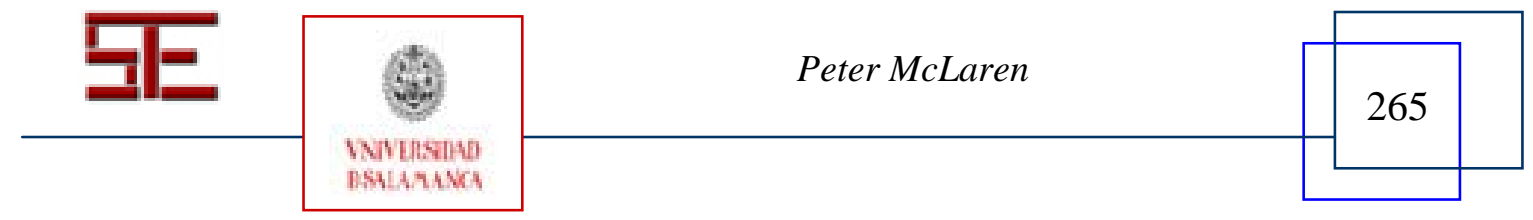


free market ideology. I look around me to the decaying infrastructures of the cities here and I feel I am living in some kind of slow-motion demolition of civilization, in a film noir comic book episode where denizens of doom inhabit quasi-feudal steampunk landscapes of wharfs and warehouses and rundown pubs, roaches sliding off laminated table cloths, in an atmosphere of dog-eat-dog despair. Those whose labor is exploited in the production of social wealth - that is, the wage and salaried class - are now bearing most of the burden of the current economic crisis in the United States and, quite simply, what is called for is a mass uprising like we saw in Argentina in 2001-2002 when four presidents were forced out in less than three weeks, like we saw in Venezuela when the popular majorities rescued President Hugo Chávez during a CIA supported coup, or like we saw in Bolivia, when the indigenous peoples put Ivo Morales in power or what we are seeing in Iceland, in Latvia, in Greece, in South Korea today. We need to cry "iQue se vayan todos!" ("All of them must go!") and flush contemporary deregulated capitalism down the toilet. But the interminably overcast political world and the media/videopshere in the US provides the US public with what Paul Valery described as "the succor of that which does not exist" -in this case, a belief that free-market capitalism is still the best of all possible systems and needed to keep democracy safe from the feral hordes of barbarians who might turn to the evil of socialism if we are not vigilant in protecting our way of life. As educators, we are faced with a tough challenge in teaching about and against capitalism.

William Tabb notes that the system itself created this crisis by floating the stock of new companies that promised to invest in high technology. Prices rose so high that the stock market came crashing down. When the Federal Reserve lowered interest rates and kept lowering them, it became easier for companies and individuals to borrow and it helped people pay off debt and borrow more and low-interest mortgages made home ownership cheaper. As housing prices rose and kept rising, mortgage originators gave out easy lowns with little or no down payment as well as low teaser-rate loans which would reset in the future were offered, and interest-only mortgages became common. Adjustablerate mortgages allowing borrowers to make very low initial payments for the first years became for popular. The banks learned to securitize these loans by selling the collateralized debt obligations to someone else who would receive the income. You would get paid up-front with money you could lend to still more borrowers. Tabb tells us that between mid-2000 and 2004, American households took on three trillion dollars in mortgages while the US private sector borrowed what three trillion dollars from the rest of the world. Almost a half of the mortgages were financed with foreign money. And when the Securities and Exchange Commission changed the rules to allow investment banks to take on a great deal more risk, we saw the collapse of Wall Street as we have known it. When the big investment banks received an exemption from regulation limiting the amount of debt they could take on, they borrowed and invested more in relation to the actual capital the bank possessed. But they ran out of money when things went bad. This is what happens when you put your faith in the magic of the market (the market is the singular most important diety in the United States) allow banks to self-regulate. Social regulation in the public interest is, and has always been -anathematic to the ruling class, or the transnational capitalist class, however you describe the guardians of the

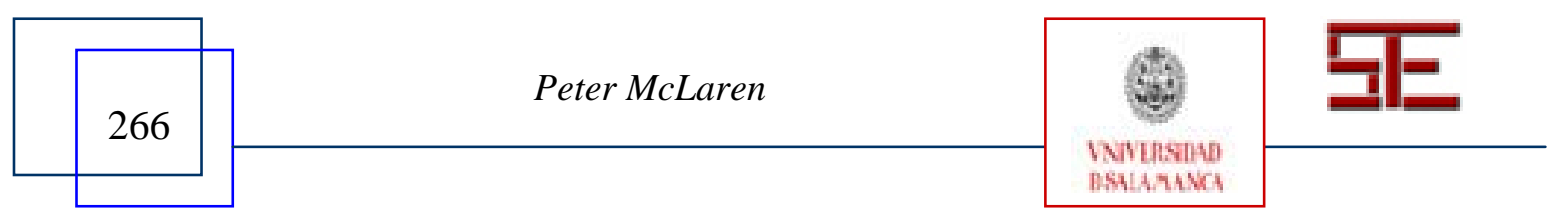




\begin{tabular}{c|c}
\hline 1 & $\begin{array}{c}\text { Revista Electrónica Teoría de la Educación. } \\
\text { Educación y Cultura en la Sociedad de la Información. }\end{array}$ \\
\hline & TESI, 10(3), 2009, 256-281
\end{tabular}

interest of capital. The ruling class and its powerful fractions of capital put the blame on too much governmental regulation — not too little - with respect to the current crisis just at a time when we need strong government action.

Because of the credit squeeze, businesses cannot get sufficient credit and so are cutting back on investment, on payroll, on employees and are not pursuing strategies to help working people — why aren't mortgage rates being lowered to let people stay in their homes? Why is money being thrown at the banks when they need to be nationalized and reorganized? We need to move to direct job creation, not giving tax breaks to corporations doing business in the US. As Tabb notes minimizing or eliminating their tax burden leaves the working people to pay more. Tabb is correct in arguing that the issue of class power and the structural nature of capitalism as a system of class domination has to be brought front and center - we need to critique the very class structure of capitalism. If we wish the patterns of taxation and pro-corporate policy we need greater social control over capital with its recurring crises and unpredictable cycles and chronic instability and a complete rethinking of the system in terms of what economic democracy really means for the wretched of the earth.

Given the nature of capitalism, and primed by the laws of capitalist competition and accumulation, capitalists are forced to produce a surplus product in order to produce surplus value; and in order to generate even more surplus value, must be reinvested and this continued reinvestment expands surplus production and there exists a continual need to discover spaces for surplus production. Capitalists are in continual search for new means of production as well as natural resources and the necessity of raw-material extraction has led to what some have called the new imperialism. What we need, obviously, is a non-capitalist class structure.

We are entering a period where leftist educators must play an important role in the global struggle with finance capital.

The most important approach to discussing the crisis in capitalism has been developed, in my view, by Glenn Rikowksi in his discussion of the social production of labor power as this relates to education. "Labor-power" is the potential or ability of workers to work, it is the latent value (or the promise of creating value possessed by human labor) that has not yet been expended. "Labor" is the actual activity of producing value. The profit or what Marx refers to as surplus value arises when workers do more labor than is necessary to pay the cost of hiring their labor-power.

Exploitation is normalized institutionally when a small minority (the capitalists) monopolizes the means of production, and workers must rely on wage labor at the behest of the capitalists. This inequity is preserved and reproduced by the state. The presence of the unemployed pressure employed workers, ensuring that they will work unremittingly hard to produce for the capitalists. So an anti-capitalist curriculum begins with the struggle for morality, which can only occur outside of capital's value form. Equality is impossible under capitalism since under capitalism it is the quality of labor power that is paramount, not the equalization of labor power. These are issues that need to be explored. Glenn Rikowski puts it this way:

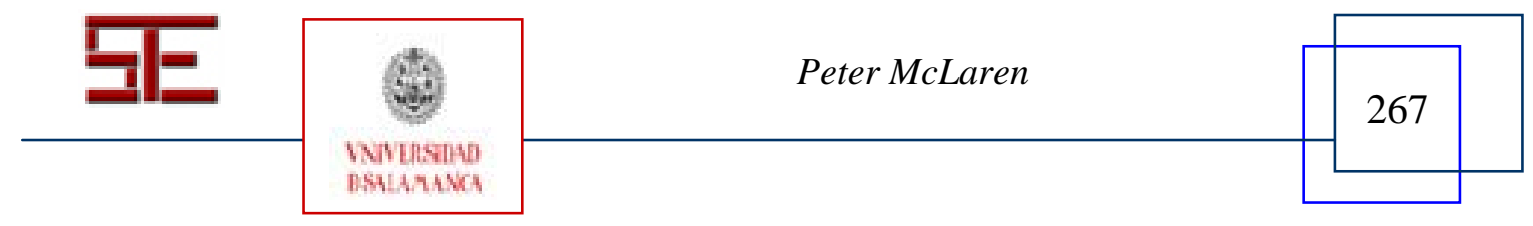


In capital's social universe, 'values' have no substance, but value is the substance. Morality, is the struggle for morality, the struggle to make it real, and this can only be a possibility (still only a possibility) in the movements of society post-capitalism. Moral critiques of capitalism are in themselves insufficient, as Marx held (though they are understandable, and may energize people and make them angry against the system, and this anger may lead to significant forms of collective struggle). However, the struggle to attain morality, the struggle to make values possible, continually crashes against the fabric of society. It is this that makes struggles for gender equality, 'race' equality and so on so explosive. In capitalist society, these forms of equality (like all other forms of equality) are impossible. But the struggle for their attainment exposes their possibility, a possibility that arises only within a post-capitalist scenario.

On this analysis, collective quests for gender and 'race' equality are a threat to the constitution of capitalist society; they call forth forms of equality that can have no social validity, no existence, within the universe of capital --as all forms of equality are denied except for one. This is equality on the basis of exchange-value. On the basis of exchange-value we are all equal. There are a number of aspects to this.

First, our labors may be equal in terms of the value they create. However, as our labor powers have different values, then 10 weeks of my labor may be equal to a single day of the labor of some highly paid soccer player. Equality here, then, operates on the basis of massive substantive inequality. Secondly, the value of our labor powers may be equal; so one hour's labor of two people with equal labor powers (in terms of labor power quality) creates the same value. In a paper of last year, I go on to show that although these are the only forms of equality socially validated within the social universe of capital, practically they are unattainable as other social drives break these forms of equalization ... For example, the drive to enhance labor power quality as between different capitals, national capitals and between individuals pursuing relative 'self-investment' in their own labor powers would constantly disrupt any systematic attempt to create equality of labor powers through education and training. Although forms of equality on the basis of exchange-value are theoretically possible, the first (equality of labor) is abominable as it is compatible with massive inequalities of income and wealth, whilst the second (equality of labor powers) is practically hopeless. The outcome of all this is that struggles against inequalities in capitalist society are struggles for forms of equality that cannot exist within capitalism. Yet they nevertheless constitute struggles against the constitution of capitalist society, and also for equality than can attain social existence on the basis of the dissolution of the social universe of capital.

Rikowski explains, after Marx, how labor power is transformed into labor in the labor process, and how, in this movement value, and then at a certain point surplus value, is generated. He illustrates that there are two aspects to labor: it is a process of producing use-values and also value (a valorization process). These are not two separate processes but both are both expressions of the one and same set of acts within the labor process. Rikowski puts it thusly:

If the product is useless then value is not realized at the point of sale. Labor power consists of those attributes of the person that are used in creating a use-value (the use-value

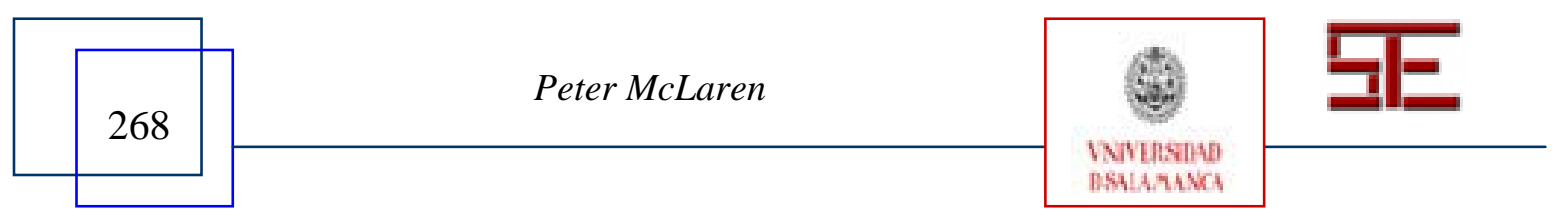




\begin{tabular}{c|c} 
Revista Electrónica Teoría de la Educación. \\
Educación y Cultura en la Sociedad de la Información.
\end{tabular}

aspect of labor power), but labor power also has a quantitative, value-aspect too. Through the activity of the worker (labor) in the labor process, some of our personal powers (labor power) also become expressed as value-generation. Thus: labor power is the unique, living commodity that is the foundation of value, the substance of the social universe of capital. We create the social universe of capital. Now, I have argued (e. g. Rikowski, 2000a) that education and training play a key role in the social production of labor power.

Rikowski argues that education and training play a key role in the social production of labor power. There exists a social drive to reduce all education and training to labor power production and according to Rikowksi this reflects the deepening capitalization of the whole of social life. In contemporary capitalist society, education and training play an incredibly key role in the social production of labor power - which Rikowski reminds us is the single commodity on which the expansion of capital and the continuation of capitalist society depend. Thus, it behooves us mightily as critical educators to understand the processes by which education and training increasingly operate as vehicles of labor power production, and —and this is crucial to remember Ravi- it is not labor but rather laborpower that generates value. Value is the substance of the social universe of capital. Education and training thus have a key role to play in the maintenance and expansion of the social universe of capital. As educators, as students, we are all involved in socially producing labor power, although teachers have more social power in this regard than do students. If we are part of the endless social drive to enhance labor-power quality then we are at the same time participating in a process that necessarily creates an inequality of labor-power values, and works against what education in capitalist society should be about, which is labor-power equalization. I am brought back one of Marx's reflections, that "The realm of freedom begins where the realm of necessity is left behind," and also, "limiting the length of the working day, is a crucial demand”.

The key here is to recognize the fundamental contradiction between the drive to enhance labor power quality, and the real necessity of labor power equalization. And the latter is not possible within the social universe of capital. Rikowski is at the forefront of this idea, and here his contributions to critical pedagogy are of inestimable importance. Business and corporate leaders realize that education is all about the reproduction of labor power for capital although, as Rikowski notes, they call it 'human capital', and this is a very scary term indeed. But it is accurate. In my writings I try to capture the alienation and fetishization and commodification of human life, of capitalism turning living laborers into abstract laborers. Here in the US the process of educating students' labor power for capital is increasingly standardized —we make sure students can take standardized, multiple-choice exams that stifle their thinking and make them less able to develop the critical skills that can help them figure out that they are fodder for the reproduction of capitalist social relations. Rikowksi notes that "teachers and trainers have huge strategic importance in capitalist society: they are like 'angels of the fuel dump', or 'guardians of the flame', in that they have intimate day-to-day responsibility for generating the fuel (labor power) that generates what Marx called the 'living fire' (labor)”. God

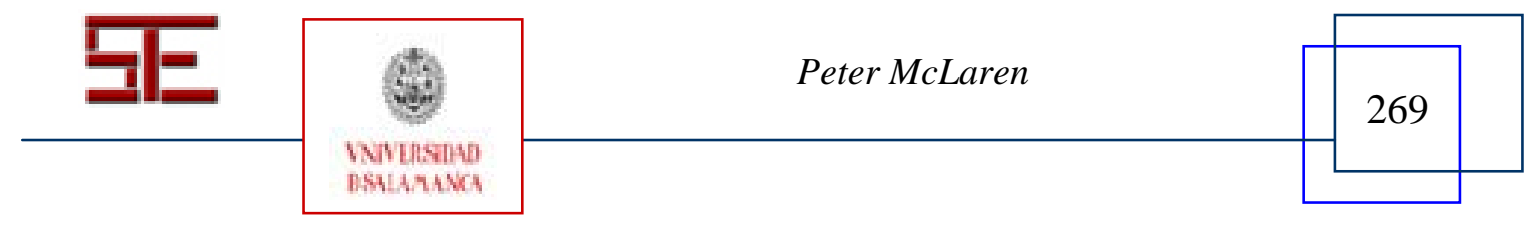


forbid that students might question the representatives of capital! So the task becomes: Who can compete best in enhancing the quality of labor power of students to further the efforts of neoliberal globalization? We, as teachers, labor for labor power production! We are learning to labor for labor power enhancement, not labor power equalization.

So how can we disturb this process? How can we subvert, unsettle, resist, rupture and confound this process? Well, Rikowski argues that we can "work to enshrine alternative educational principles and practices that bring into question the constitution of society and hint at ways in which expenditure of labor power does not take a value form”. We are constituted by labor and capital and this contradiction plays itself out within the deep recesses of our psychologies (as the psycho-Marxism has shown us).

We are constituted by the concrete, qualitative, use-value aspect; and secondly by the the quantitative, abstract value-aspect of labor and we are produced, necessarily as 'living contradictions'. We are, assuredly, propelled by the movement inherent in this living contradiction in the direction of transforming ourselves by changing society (by the coincidence of changing circumstances and self-change, as Marx would put this notion we call revolutionary praxis), and through this by struggling to build a social universe outside of capital's value form. So we can begin this task when we acknowledge how we can't have real equality through exchange-value, but only on the basis of the equalization of labor power, or the equality of valorization of labor-powers. And why? Rikowski hits the socialist nail into the capitalist coffin when he says:

This is because the inequalities of labor-power quality generated within the capitalist labor process require re-equalisation to the socially average level in order to attain the equalisation of labor-power values that is the foundation of social justice in capitalism. As individual capitals are responsible for generating these inequalities, then they are responsible for re-engineering labor-power equality. Thus: capitalist enterprises are responsible for providing compensatory education and training in order to equalise laborpower values. As this process has indeterminate effects regarding surplus-value creation, which is the basis of capitalist profit, it is unlikely that, in practice, representatives of capital (employers) would pick up the tab.

Now here we can see why Rikowski notes that "social justice on the basis of capital exists only in the form of a mode of social life denied" precisely because the struggle for labor-power is annulled by capital's social drive to enhance labor-power. We need to focus not only on social relations within the classroom but to take into serious account the quality of social relations in all organizations seeking to transform capitalist society. Here, all of us - whether we are teachers in classrooms, or workers in factories, or working in retail at the local boutique - are encouraged to become critical revolutionary educators. So, along with Rikowski, Paula Allman, Dave Hill, and Mike Cole, and others, I would like to see educators put into practice the critique of capitalist production and this should include, as Rikowski emphasizes, the production of teacher work and its relationship to social domination in capitalist societies. And, of course, needed are theorizations and strategies of how labor power can be used by workers in the service of anti-capitalist activity. As Rikowski notes: labor power is the supreme value-creating power on which capital depends for its existence, and it is incorporated within laborers

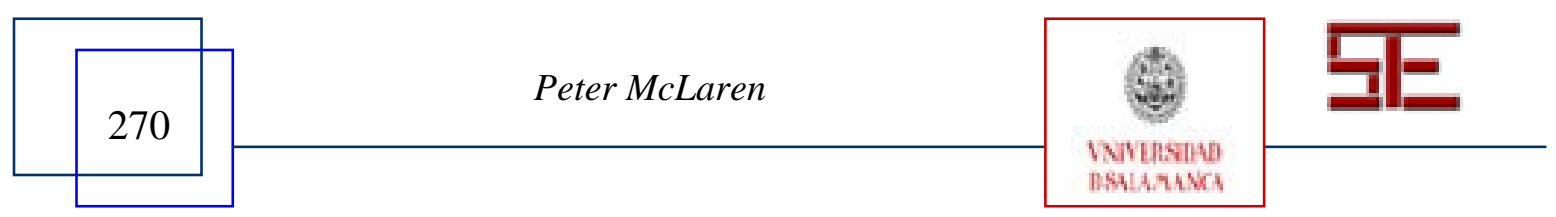




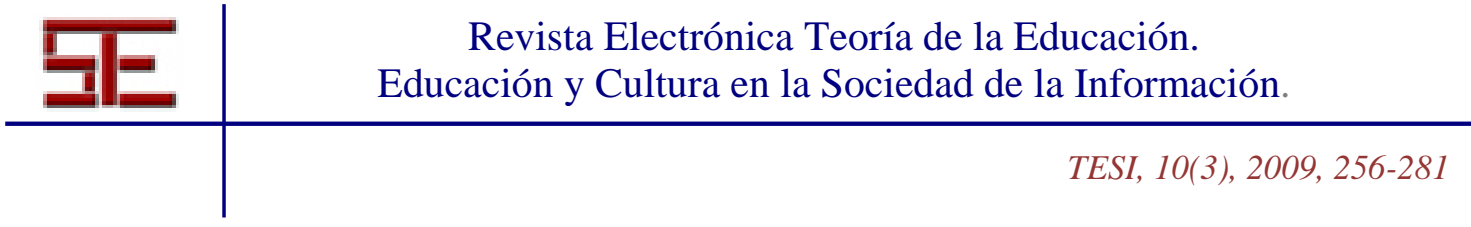

who have the potential to withhold this wonderful social force (through strikes or leaving the employment of a capital) or worse, to use labor power for anti-capitalist activity and ultimately for non-capitalist forms of production. Together, these features make labor power capital's weakest link. Capital depends on it, yet has the capacity to be used by its owners against capital and to open up productive forms which capital no longer dominates. Marx and Marxist analysis uncovers this with a great force and clarity as compared with any other critical social theory.

So insofar as we are able to, as Rikowski puts it, "critique the ways in which human labor constitutes capitalist society (how we become dominated by our own creations) and the constitution of capitalist society in terms of its basic structuring features" we are building the foundation for a truly critical pedagogy. Here we can ask ourselves how we become constituted - I would even use the word "enfleshed" — by the following aspects of labor power summarized by Rikowski, below:

1. The value aspect of labor (power): the quantitative aspect.

2. The use-value aspect of labor (power): the qualitative aspect.

3. The exchange-value aspect of labor (power): the aspect that determines the equality of labours and labour powers.

4. The subjective aspect of labor (power): the will determined aspect.

5. The collective aspect of labor (power): the co-operative aspect (involved in workers working together).

6. The concrete aspect of labor (power): the particularities and peculiarities of labor and labor power attributes involved in specific labor processes and in specific work roles.

Secondly, and here I am following Rikowski's typology of what a truly revolutionary critical pedagogy would look like, I would explore how inequalities are generated by capitalist society —racialized inequalities, patriarchal inequalities, inequalities bases on differential treatments of various social groups. The third moment in Rikowski's architectonic is his recomendation that we critique of all aspects of capitalist life. Rikowski summarizes this as follows:

It is based on the works of Marx and Marxism, first and foremost;

The starting point is the critique of the basic structuring phenomena and processes of capitalist society which involves a critique of the constitution of capitalist society;

The second most significant level of critique is the host of social inequalities thrown up by the normal workings of capitalist society and issues of social justice can be brought in here;

The third level of critique brings in the rest of capitalist social life but relates to the first and second levels as frequently as possible;

Two keys fields of human activity in contemporary society stand in need of fierce critique: capitalist work and capitalist education and training (including the social production of labour power);

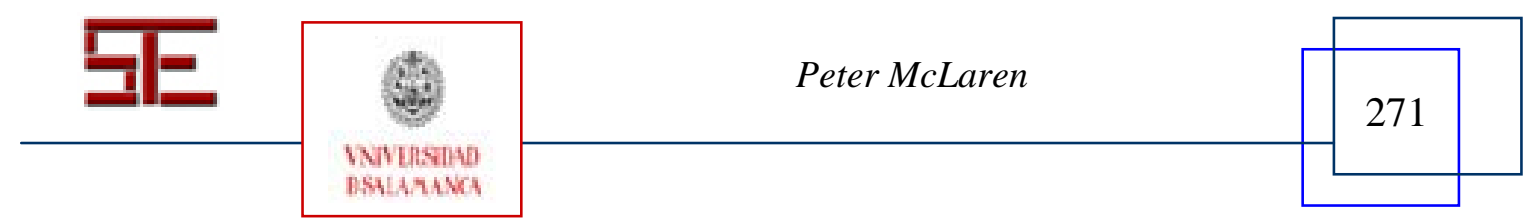


Labor power as capital's 'weakest link' deserves special attention as it has strategic and political significance.

I would add another feature to the schema Rikowski has provided. For me, since the value form of labor (abstract labor) that has been transmogrified into the autonomous moment of dead labor, eating up everything that it is not, can be challenged by freely associated labor and concrete, human sensuousness we need to develop what I call a philosophy of revolutionary praxis. This involves envisioning a non-capitalist future that can be achieved by means of subjective self movement through absolute negativity so that a new relation between theory and practice can connect us to the idea of freedom. As Peter Hudis argues, the abolition of private property does not necessarily lead to the abolition of capital so we need to push further, to examine the direct relation between the worker and production. Here, our sole emphasis should not be on the abolition of private property, which is the product of alienated labor; it must be on the abolition of alienated labor itself. As I have mentioned before, Marx gave us some clues as to how transcend alienation, ideas that he developed from Hegel's concept of second or absolute negativity, or 'the negation of the negation'. I've written about his, and it comes mainly from the work of the founder of Marxist humanism in the United States, Raya Dunayevskaya. In addition to this we need an approach to decolonizing pedagogy, and its not just a question of the epistemicide - the epistemological violence visited upon pedagogies (including pedagogies of liberation) via Eurocentric teaching philosophies and practices - but a question of pedagogies driven by neo-liberalization, involving themselves, both in tacit and manifest ways, in spreading market ideology. This is where I support President Hugo Chávez, and movements in Latin America that are antineo-liberalization.

5. The election of Obama has reintroduced the debates on race and whether class can be termed the primary category and fundamental basis of social structure. Obama in a recent interview said "that ...everybody's learned their lesson. And the answer is not heavy-handed regulations that crush the entrepreneurial spirit and risk taking of American capitalism. That's what's made our economy great. But it is to restore a sense of balance". Given such deep commitment to capitalism one cannot expect him to revert back on what neoliberal assault has done, even though majority of Africanamericans are poor and pauperized, worst affected by recession. In such case Obama would not have greater sympathies for his race. Private capital, which helped him amass largest ever election fund will remain his priority. How do you see this situation?

Well, I am going to answer this using some comments I made in a recent article about the election that is in press here in the United States. The recent presidential election was perhaps little more than a rehearsal for a return of the same, a pretext for the restatement of business as usual in a different voice, whose message is more about timbre and pitch than policy —a rewriting of the old (the Leibnizian "we live in the best of all

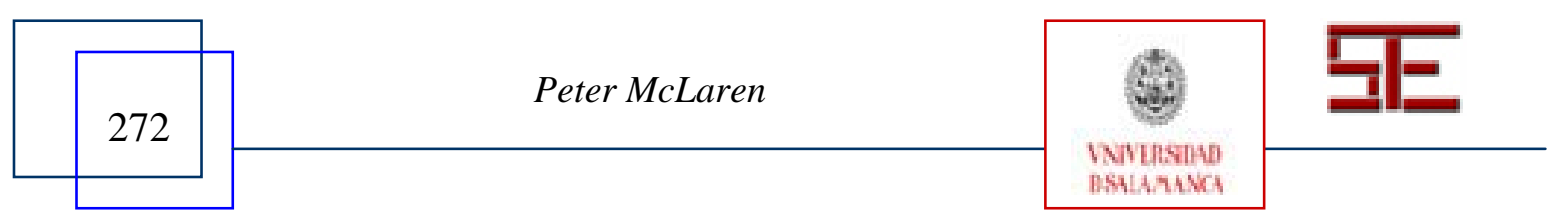




\begin{tabular}{c|c}
\hline 1 & $\begin{array}{c}\text { Revista Electrónica Teoría de la Educación. } \\
\text { Educación y Cultura en la Sociedad de la Información. }\end{array}$ \\
\hline & TESI, 10(3), 2009, 256-281
\end{tabular}

possible worlds") in the new subjunctive language not simply of hope and possibility (what if?) but of resounding and reverberating hope and possibility ('what if' meets 'we shall'), delivered in the Horatio Alger-Joins-the-Orange-Revolution aerosol discourse of "Yes We Can!". This is because the hope of which Obama speaks is impossible to achieve under capitalism. Even if Obama has the best intentions, the rules of the game prevent the kind of difference that will make a real difference. Everything that could conceivably bring about the kind of social transformation that will dramatically change for the better the fabric of everyday life in America is unmasked as an impossible contradiction if we place it in the context of the persistence of capitalism as the only alternative way to organize the globe for overcoming necessity. Of course, we won't place it in such a totalizing context (isn't totalizing one of the bete noirs of the Marxists, according to poststructuralist pundits?), but will focus on the subjective nature of the trauma or on the cultural aspects of the global crisis in which we are living rather than analyze the structural of systemic roots of the crisis).

In this regard, the election could be likened to a media virus programming its own retransmission via a well-worn template that has no entrance for the critic and no exit for the cynic. And no substance whatsoever. Participant spectators trying to use their ballot for political change find themselves sucked right back into a social universe of diminishing expectations and endless spectacle that keeps them narcotically entrained in a strange loop of sound-byte aphorisms. It's forcing them to chase their tails inside what resembles a fetishized moebius strip absent any counterpoints or counternarratives, devoid, in other words, of contextual or relational thinking. Or following the hands of an Escher drawing where the sketch dissolves into the artist then dissolves back into the sketch, ad infinitum; illusion and reality appear an endless dance with little chance of breaking out into a new moral, political or economic logic through some form of metacommunication or metapraxis - after all, who is there to listen except the already insane?

The unwitting victims, the popular majorities, have once again fallen prey to a contagion of manipulation, of an endless circularity of mutual determinations that spreads like a bacilli in a fetid swamp disguised as a golden pond that sports at its center a shining marble fountain spurting audacious hope like a geyser of yellow ink. Obama's fountain of national renewal.

The mainstream media coverage of the election created a vortex of political indeterminacy, of radical contingency - a multi-temporal, non-synchronous dynamic internal to the mechanisms of the election coverage as such - that encouraged anti-dialectic analyses of the issues facing the America public, causing its coverage to slip and slide and remain unfastened to any coherent historical narrative of social change, making contextual thinking impossible and blurring the distinction between illusion and reality, between the cadaver and the autopsy that follows. The historical and contextual rudderlessness of the media created a conceptual field in which real transformation cannot be conceptualized. Such is the nature of the corporate media.

The election was a media spectacle that served as little more than an allegorical background for the battle for the soul of America. The media used our ballots to reproduce at

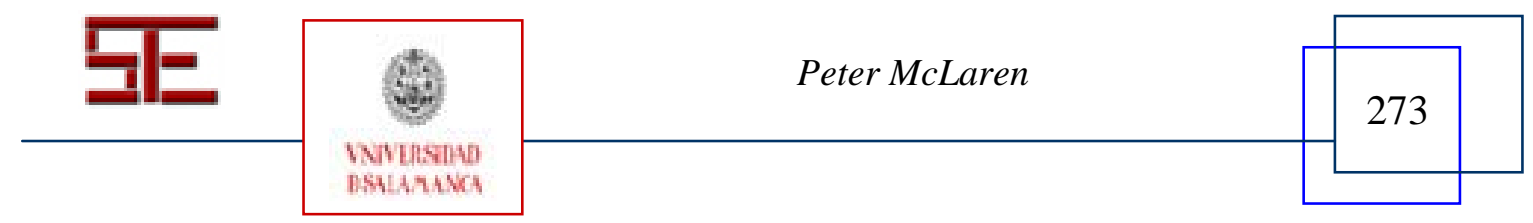


the level of action the symbolic violence they export daily at the level of ideas. The goal is to get a neoliberal of the right or the left elected — somebody who will not challenge the presuppositions of the transnational capitalist class. In the interests of subverting the Bush regime, voting Democrats became organs of the body politic, subverting their own interests in the belief that their votes would matter, that they had the power to explode the limits or the self-contained subjectivity of our media-educated expectations and conditioned political agency.

The conservative recipe for economic well-being tax cuts and low inflation through monetary policy controls and unfettered and unregulated markets cannot succeed under global neo-liberal capitalism. The overall savings rate of Americans (it's been dropping since 1997) failed to increase with tax cuts. Supply-side economics pivots on a small number of Americans controlling a significantly large amount of the nation's total income $1 \%$ of Americans that the GOP's tax policies have favored-and this policy has clearly failed the poor. Deficit spending did grow the economy by 20 percent during Bush's tenure but between 2002 and 2006, it was the wealthiest 10 percent of households that saw more than 95 percent of the gains in income. Deregulation simply became a criminal enterprise of making more and more profits. But the real question is whether or not the system of capitalism itself is criminal. Without answering this fundamental question, we focus on the salaries, benefits and bonuses of the top executives that are getting taxpayer bailouts from Washington. We bristle at the executive largesse in terms of cash bonuses, stock options, and personal use of company jets (the average paid to each of the top executives of the 116 banks now receiving government financial aid was \$2.6 million in salary bonuses and benefits) - the total amount would actually cover bailout costs for many of the banks (so far they have received 188 billion of our taxpayer dollars) that have accepted tax dollars to keep afloat. So while we fume about Wells Fargo of San Francisco, which took \$25 billion in taxpayer bailout money with one hand and gave its top executives up to $\$ 20,000$ each to pay personal financial planners with another, we would do well to focus more on our complacency with respect to capitalism as the only system under which democracy can flourish (and that's quite an assumption about the state of democracy in this country).

The richest 400 Americans own more than the bottom 150 million Americans combined; their combined net worth is \$1.6 trillion. During the Bush years, the nation's 15,000 richest families doubled their annual income, from $\$ 15$ million to $\$ 30$ million and corporate profits shot up by 68 percent while workers' wages have been steadily shrinking (and the workers are not the ones who are being bailed out by the government). That scenario isn't about to change radically with the election of Obama, who might possess Jeremiah's aliveness to spiritual vision (don't his hands look light lighted candles when he speaks) but is unwilling to unmask and name the powers that be because, well, for one thing, he is that power.

Predictably, the Republican spin machine, FOX News, is trying to stave off a New Deal type of depression recovery program discussed by Obama by claiming that most historians agree that Roosevelt and the New Deal actually prolonged the Great Depression. Of course, this revisionist reading of history sounds even silly to freshmen college stu-

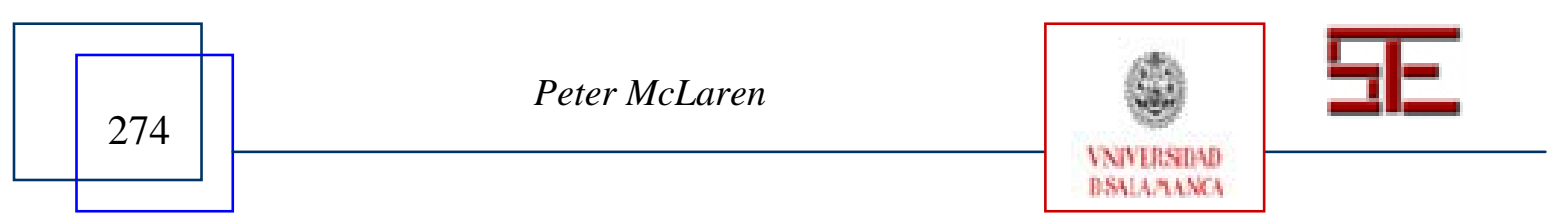




\begin{tabular}{c|c}
\hline 1 & $\begin{array}{c}\text { Revista Electrónica Teoría de la Educación. } \\
\text { Educación y Cultura en la Sociedad de la Información. }\end{array}$ \\
\hline & TESI, 10(3), 2009, 256-281
\end{tabular}

dents, but if it gets repeated often enough, it will be received by FOX TV's hapless listeners as if it were regurgitated from the bowels of the gospel.

We haven't seen the worst of the economic crisis. And while we might not see a return to the orphan trains of the 1920s, where hundreds of thousands of homeless and orphaned 'street urchins' were taken to small towns and farms across the United States as part of a mass relocation movement of destitute children and unloaded at various train stations for inspection by couples who might want to adopt sturdy children to help them work the farms, we can be sure that children will be suffering through the current recession along with their parents.

The media — the instruments of the cultural commonsense of the social — are structural features of capitalist society and thus part of society's social practices and as such must be linked to larger historical developments linked to wider social forces and relations. Seen in this light, it becomes clear that the media supports those institutions that undercuts the collective needs, rights, and causes of workers and sullies any fertile ground in which social struggles might take root that can challenge capital on behalf of labor and the global working-class. In other words, the corporate media normalize the social division of labor and the ruthless exploitative practices needed to keep this division in place. Different blocs of capital must expand in order for capitalism to survive, and this means extracting the most profit possible. This essentially determines what gets produced, how, and by whom. It accounts for why one is six children worldwide are child laborers, and why corn, sugar and are now often produced in the so-called Third World not to feed the hungry but to provide biofuels for advanced capitalist countries. This is why education and health care systems in the United States are in tatters.

As racism became the torch of hope for the electoral victory of the Republican Party, millions of Americans decided that the juggernaut of hate riding on a crest of bile was too much for the American public and a groundswell of support for Obama - largely made possible by the organizing skills of the antiwar movement and the popular leftwas just enough to change the tide of history. To what extent the left can keep the pressure on the Obama presidency to focus on the unemployed at least as much as on the beleaguered industries remains to be seen. And even if it managed to keep the pressure on, there is no guarantee their voices will be heard as Obama has shifted center-right since his election victory and seems bent on getting US troops further bogged down in Afghanistan. Regular "America at War" features on media outlets are sure to be there as long as US capital seeks to impose its will on foreign markets and serve as the alpha male for the transnational capitalist class.

And what about race? Since people of color still lag well behind whites in almost every major social, economic and political indicators, Eduardo Bonilla-Silva (2008) asks whether Obama will contest the new system of racial practices what Bonilla-Silva calls "the new racism" - that is co-structured by a new racial ideology called "color-blind racism". In other words, is Obama a post-civil rights minority politician (i. e., an antiminority minority Republican or post-racial Democrat) who is successful because he does not directly challenge the white power structure? Bonilla-Silva argues that social movement politics and not electoral politics is the vehicle for achieving racial justice.

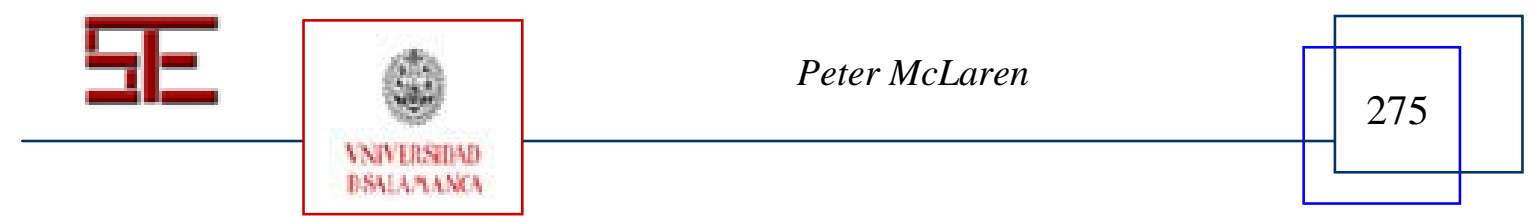


And he notes that Obama's policies on health care, immigration, jobs, racism, the war in Iraq and the Palestinian question are not radical, that he has made a strategic move towards racelessness and that he has adopted a post-racial persona and political stance. Obama doesn't like to talk about racism (and when he does likes to remind people he is half white) and unlike black leaders unpopular with whites (such as Jesse Jackson, Maxine Waters, and Al Sharpton) even suggests that America is beyond race. Bonilla-Silva writes that Obama works as a "Magic Negro" figure:

Obama also became, as black commentator David Ehrenstein has argued, the "Magic Negro" - a term from film studies that refers to black characters in movies whose main purpose is to help whites deal with their issues. In this case, voting for Obama allowed many whites feel like they were cleansing their racial soul, repenting for their racial sins, and getting admission into racial heaven! Obama became whites' exceptional black man - the model to follow if blacks want to achieve in America!

For many nonwhites, particularly for blacks, Obama became a symbol of their possibilities. According to Bonilla-Silva (2008).

He was indeed, as Obama said of himself, their Joshua-the leader they hoped would take them to the Promised Land of milk and honey. They read in between the lines (probably more than was/is there) and thought Obama had a strong stance on race matters. For the old generation desperate to see change before they die (Jackson crying, John Lewis, etc.), and for many post-Reagan generation blacks (william from The Black Eyes Peas) and minorities who have seen very little racial progress during their life, Obama became the new Messiah following on the footsteps they did not such much as Martin and Malcolm.

But as Bonilla-Silva remarks, Obama's policies on race matters were not that much different from Hillary's, he was the darling of the Democratic Leadership Council, his economic and health care programs are modest, he wants to expand the military by 90,000, intends to redeploy troops from Iraq to Afghanistan, is a big supporter of freemarket capitalism and his policies on Cuba, Venezuela, North Korea and Palestine and no better than Hillary's. But many Obama voters believed (and many continue to believe) that "these are tactical positions Obama needed in order to get elected" and many of his positions are temporary, and Obama will suddenly turn left when he takes office. Obama's really a "stealth candidate" -a revolutionary about to announce a far shift to the left that will have both liberals and conservatives quaking in their boots. The fear those Bonilla-Silva (2008) raises - that "the voices of those who contend that race fractures America profoundly may be silenced” in Obameria - are real, and that Obamerica may bring us closer to the racial structure of many Latin American countries:

We may become like Brazil, Cuba, Mexico, Belize, or Puerto Rico — nation states that claim to be comprised of "one people" but where various racial strata receive social goods in accordance to their proximity to "whiteness". And like in Latin American countries, Obama's nationalist stance ("There’s not a black America and white America and Latino America and Asian America; there's the United States of America”) will help close the space to even talk about race. Hence, in Orwellian fashion, we may proc-

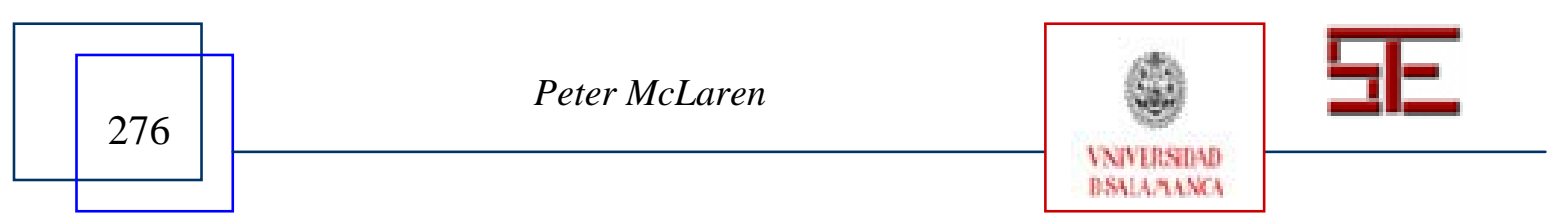




\begin{tabular}{c|c}
\hline 1 & $\begin{array}{c}\text { Revista Electrónica Teoría de la Educación. } \\
\text { Educación y Cultura en la Sociedad de la Información. }\end{array}$ \\
\hline & TESI, 10(3), 2009, 256-281
\end{tabular}

laim "We are all Americans!, but in Obameria, some will still be "more American than others".

And while clearly racial justice has been retreating to its lowest point since the Kerner Commission Report announced 40 years ago that "Our nation is moving toward two societies, one black, one white — separate and unequal" the election of Obama is unlikely to signal a permanent reversal of this trend.

Can Obama take on the military establishment? The corporate structure? Sheldon Wolin notes that we live in an "inverted totalitarianism" in which the entertainment industry via spectacles and diversions is able to keep the citizenry politically passive, as long as there exists a reasonable standard of living. Even if there are more popular protests due to the economic crisis, the media will ignore them. In my view, Ravi, we need more Battle of Seattle, in every city, simultaneously!

\section{In your work Capitalists and Conquerors, you argue that schools teach students skills that is required by capital and even their dreams are limited to the sphere of capital. The desire to transcend the rule of capital is suppressed through the mechan- ics of school. This also invokes the Althusserian idea of ideological state apparatuses. How does one counter this suppression?}

I have tried to give you the basics of this answer in my discussion of Glenn Rikowski's path-breaking work on teaching for an anti-capitalist future. I have had trouble, myself, taking on the ideological apparatuses of the state, especially after a right-wing group in 2006 launched an attack on me and my fellow leftist professors at UCLA, placing me as the number one figure in their Dirty Thirty list, as the most dangerous professor at UCLA. Steve Best, Tony Nocella and I have just finished editing a book on academic repression. In the introduction we discuss right-wing pundits such as David Horowitz, who has penned an Academic Bill of Rights. The introduction to the book describes the Academic Bill of Rights as a thinly veiled Trojan horse that threatens the core values and very life of academia. Horowitz's clever tactic is to use liberal/Left discourse to advance an extreme rightwing agenda that strips professors or any professor not a totally brainwashed product of American society and its capitalist values of their right to publish, teach, and act as citizens as they wish. What the Academic Bill of Rights attempts to do is to give the already advantaged and over-privileged more power than the surplus stock it already holds. "Intellectual diversity" and such phrases are merely code words for empowering rightwing ideologies. It's call for "balance” is really a ploy for imbalance, for a pre-60s sterile groupthink, conformist environment dominated by conservative thought without any diversity among faculty, programs, courses, and intellectual life (if there would be one at all). Unable to think outside of the corporate box and utilitarian model of education, they have no idea what real education is, a mission that includes encountering and engaging differing viewpoints; students would be denied this opportunity. It is healthy and vital for conservative students to hear radical perspectives, as it is for progressive students to hear conservative perspectives.

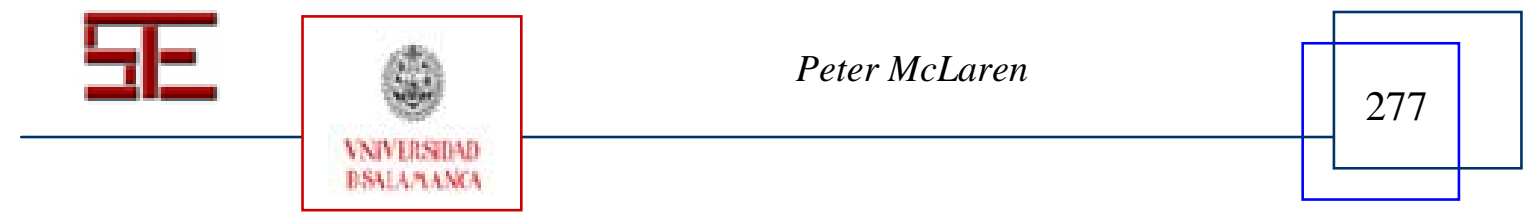


The truth of the matter is, Ravi that the stranglehold of corporate power on the universities is choking the life out of whatever remains of the university's role as a vehicle for the advancement of public life. Some of us are directly involved in fighting for academic freedom, and resisting the capitalist and imperialist values that the universities are coming to enshrine through curricula, business partnerships, and the like. Our battle in the schools of education, housed in universities, is through the advancement of critical pedagogy. Critical pedagogy is under ideological assault, both here and elsewhere, such as Australia. Bill Ayers, the distinguished leftist at the University of Illinois, Chicago, who was a member of the Weather Underground in the 1960s, was demonized recently by the Republican Party during the Presidential election, since Ayers and Obama knew each other as fellow community activists in Chicago. So the demonization of Ayers has also spread to a demonization of so-called "critical" educators in general, some of whom who are tarred with the same brush as being anti-American and proterrorist. These are tough times for the educational left. Very tough times.

7. The resistance to this suppression becomes furthermore difficult when one finds, what you call "reproletarianisation" of teachers. Given this situation we encounter certain problems, as in the case of India. There are teachers who are employed till the age of "retirement" with different kinds of benefits and their unionisation is limited to demands for salary raise. On the other hand, there are teachers who are employed on contract with meager salary (in many cases as low as \$20) by government. In a sense while there is a 'teaching aristocracy' that does not consider itself worker and on the other a pauperized teaching labour force which is non-unionized. The role of the Left forces in these cases has been dismal. Where does resistance begin in such cases?

Yes, the same is true here. Teaching assistants in universities in many cases do the bulk of the teaching yet they get little compensation and protection. Many students want a few waivers so they can go to school while they teach and not pay tuition. Budgets are currently being slashed, and tuition fees are rising dramatically. Historically, it's been a tough battle to get academic student employee unions recognized. A university, no longer protected by the market as they once were through funding by the state, is relying more and more on corporate funding that invests in technology-based research, research that can make the corporations more effective and help to make them dominant in the neoliberal capitalist economy. Professors especially those in the hard sciences put as much, if not more, effort in getting research funding and doing research than teaching, and of course the class sizes are ever-increasing and there is a decrease in the number of full-time, tenured professors teaching classes and there is the necessity for more cheap intellectual part-time labor in the form of teaching assistants. So strong union movements are needed to protect teaching assistants, since they face a difficult task. Clearly, the labor aristocracy needs to be challenged. There needs to be joint-efforts between tenured professors and teaching assistants, they have to form a united front and work together with the unions to take on the universities. This type of united front is

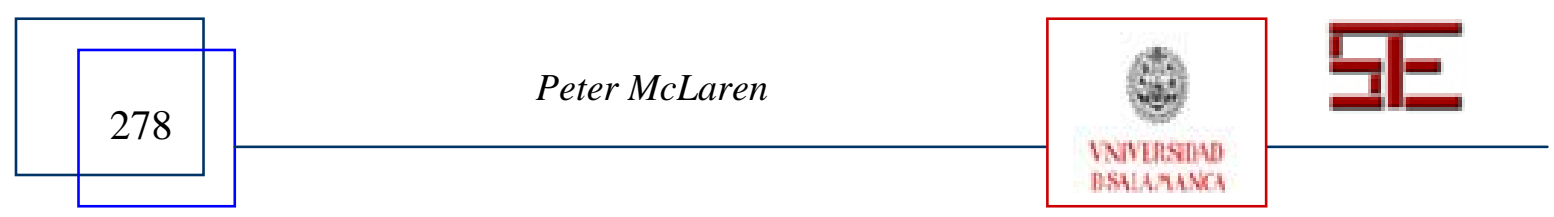




\begin{tabular}{c|c} 
Revista Electrónica Teoría de la Educación. \\
Educación y Cultura en la Sociedad de la Información.
\end{tabular}

needed, and it should have a common purpose of saving the university from becoming just another sub-sector of the economy. All of this revolves around developing an understanding of how social institutions need to reorganize themselves in tandem with the reorganzation of society as a whole to fight the capitalization and commodification of subjectivity, to fight universities whose mission is to educate labor power for capital, and such a valorization process can only lead to structured hierarchies of power and privilege that serve the few, and bring misery to the many.

8. This crisis is augmented by the increasing significance of a non-political, anticapital, anti-class gang of people (also called activists) who do not approach the problems under capitalism such as the issue of displacement of millions of Indian (caused by 'developmental' projects) as by products of a system that needs to be overthrown in final stage to prevent such callous and insensitive treatment of masses. The World Social Forums or the Narmada Bachao Andolan (movement against a big dam on river Narmada because it displaced millions) have been criticized on such lines. Where does one place the role of such an 'opposition'?

Well, clearly we need to insist on the priority of affiliation political commitments based on the basis of moral and political judgement rather than a politics of filiation, or ethnic belonginess. But this mandates that activists examine critically social relationships in their totality, that is, in the context of their relationship to the greatest totalizing force history has ever known capitalism.

The 1999 battle of Seattle summoned a collective "ya basta!" that saw the closure of a meeting of the World Trade Organisation (WTO) and since that time the WTO, World Bank and IMF have been forced to conduct their business behind police barricades. Initially the WSF forum succeeded in creating an anti-hierarchical and non-vanguardist space for the grassroots left to give collective voice to a critique of global capitalism and its attendant abuses. But it soon became taken over by established political parties of a leftist bent who promoted reformism and various forms of accommodation to capitalist accumulation and the law of value, and also gave way to the glamor politics of major celebrity speakers. The question that has been posed to the WSF by James Petras and others is: To what extent does WSF dissent become a fashionable guerilla apostasy and to what extent does its work actually threaten the interest of global capital? The fundraisers, after all, set the agenda. And many of the sponsors of the WSF are hardly radical institutions. What is heartening is the recent declaration of the Assembly of Social Movements at the recent WSF in Belem, Brazil, 2009. Here the social movements who are in solidarity with the efforts by feminist, environmentalist and socialist movements maintain promisingly that the current global crisis "is a direct consequence of the capitalist system and therefore cannot find a solution within the system". They write: "All the measures that have been taken so far to overcome the crisis merely aim at socialising losses so as to ensure the survival of a system based on privatising strategic economic sectors, public services, natural and energy resources and on the commoditisation of life and the exploitation of labour and of nature as well as on the transfer of

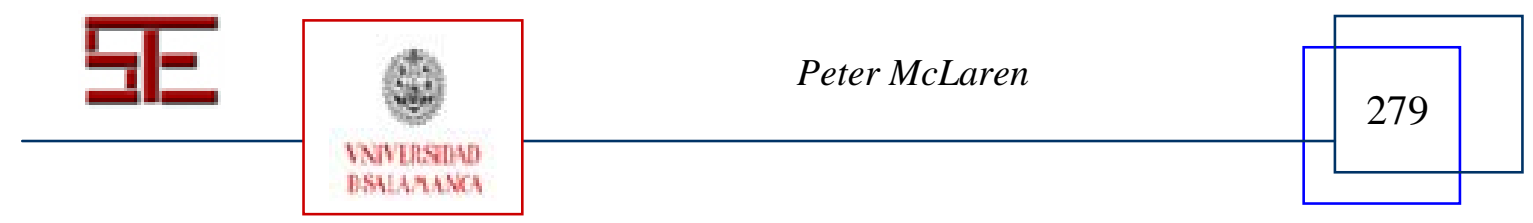


resources from the Periphery to the Centre and from workers to the capitalist class”. An important consensus has been reached that a radical alternative is necessary that would do away with the capitalist system.

Nationalising the banking sector without compensations and with full social monitoring. Reducing working time without any wage cut.

Taking measures to ensure food and energy sovereignty.

Stopping wars, withdraw occupation troops and dismantle military foreign bases.

Acknowledging the peoples' sovereignty and autonomy ensuring their right to selfdetermination.

Guaranteeing rights to land, territory, work, education and health for all.

Democratise access to means of communication and knowledge.

Here, we can appreciate the fact that forms of ownership that favor the social interest are supported and advanced: small family freehold, public, cooperative, communal and collective property.

But all of this is a cautionary tale: The mass movements and trade unions can always be co-opted by center-left regimes or even center-right regimes. As critical educators, we must work tirelessly to broaden our political project to include the support of social movements seriously challenging the distribution of public wealth and the destruction of local habitat and economies by multinational corporations. As Petras argues, social movements must work towards developing national cadre structures so that they have a chance to take state power without state power, little can be done to seriously challenge the power of the transnational capitalist class. Needed more than ever, Petras argues, are concrete organizations of struggle rooted among radical youth and among 'employed' as well as 'informal workers' in a broad effort at socialist revival and renewal that will ensure socialist organizations make stronger organic links with everyday anticapitalist struggles. Direct intervention of conscious socialist political formations deeply inserted in everyday struggles capable of linking economic conditions to political action is, according to Petras, the only way forward. That is the point at which we must secure our opposition to the rule of capital.

9. It is significant to talk of such categories of 'opposition' because at a certain plane, their acts have furthered the idea of education as autonomous in itself. Hence, we find thousands of 'alternative' schooling systems which rarely link the flaws and fallacies in education system to the rule of capital. The dialectics of labour and capital, or system and education machinery is missed out by such experiments and so is the simultaneity of reform and revolution. How do you see resistance to capitalism and its education system coming up?

Yes, there is danger in presenting education as autonomous, as unconnected to the totality of capitalist social relations. Here in the US, we have charter schools, and alternative schools, but very few of them, to my knowledge, teach from an anti-capitalist perspective. Such schools assume, ideologically, left liberal (i. e., reformist) positions but at

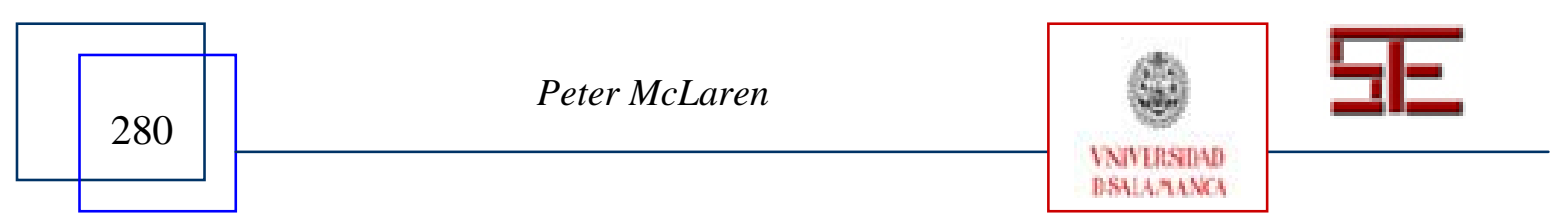




\begin{tabular}{c|c} 
Revista Electrónica Teoría de la Educación. \\
Educación y Cultura en la Sociedad de la Información.
\end{tabular}

the level of practice they amount to left neo-liberalism, since by not challenging the law of value in capitalist societies, they implicate themselves in the widening economic gap between the rich and the poor.

10. Lastly, you argue that schools should become "sites for production of both critical knowledge and sociopolitical action". How do you see this happening given the complex relationship of schools, system (run by private capital), and pauperizing mass of people? What direction should the analysis of educational ills take?

Well, I believe that my previous answers have mainly addressed your final question, and I can only add the following point whatever strategies we adopt in our analysis of education, they need to have a transnational reach. Which is why it is important that we are having a conversation such as this, since we are in the process of charting out a transnational anti-capitalist agenda on the part of educational workers, global citizens who fight both locally and globally for bringing about a socialist future. Now the first step is to become aware of the perpetual pedagogies at work that normalize the rule of capital the corporate media, the new computer and communication technologies, and all of the ideological state apparatuses that serve to legitimize capitalist social relations. We need to become critically literate about how all of these media function through multiple literacies, and how the new technologies work in the process of self and social formation. Once we know how they work in the process of ideological production, we can develop ways to interrupt their efforts and counter them. Our classrooms, community organizations, alternative media, and social movements can become sites for the creation of a counter-public sphere in which we can strengthen and coordinate our efforts to build national and transnational cadres but this requires that we work to take state power, and develop the skills to recreate the state from the bottom up in protagonistic and participatory and democratic ways.

Para citar el presente artículo puede utilizar la siguiente referencia:

McLAREN, P.: (2009): Being, becoming and breaking-free: Peter McLaren and the Pedagogy of liberation, en FLECHA GARCÍA, R. y STEINBERG, S. (Coords.) Pedagogía Crítica del S. XXI [monográfico en línea]. Revista Electrónica Teoría de la Educación: Educación y Cultura en la Sociedad de la Información. Vol. 10, nº 3. Universidad de Salamanca, pp. 256-281. [Fecha de consulta: dd/mm/aaaa].

http://campus.usal.es/ revistas_trabajo/index.php/revistatesi/article/view/3974/3996

ISSN: 1138-9737

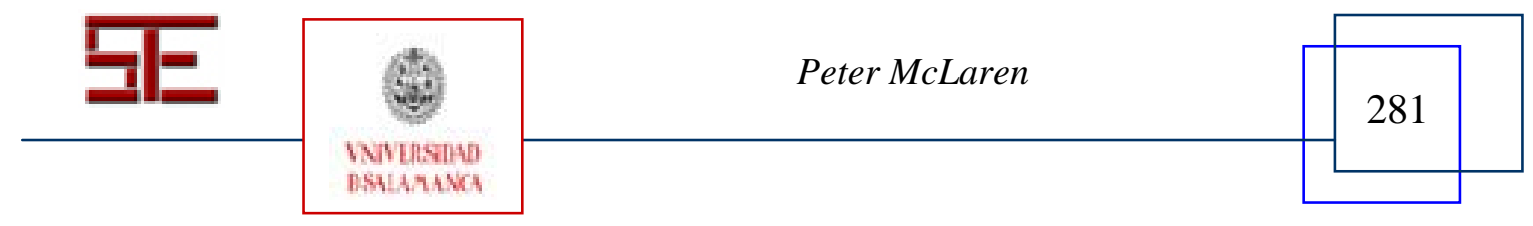

